\title{
EHMTI-0196. Tension type headache - the correlation between pain intensity, depressive symptoms and impairment of daily functions
}

\author{
M Bosnar Puretic , A Lovrencic-Huzjan, V Vukovic Cvetkovic, V Basic Kes \\ From 4th European Headache and Migraine Trust International Congress: EHMTIC 2014 \\ Copenhagen, Denmark. 18-21 September 2014
}

\section{Introduction}

Tension type headache is the most common type of headache. Although it is not a serious medical condition, in the general population it is the main cause of analgesics use.

\section{Aim}

The aim of this study was to estimate intensity and other qualities of pain as well as the influence of pain on daily functions, the presence of depressive symptoms and their correlation with pain intensity in patients with tension type headache.

\section{Patients and methods}

It was a prospective study performed at the University Department of Neurology, Sestre milosrdnice University Hospital Centre, Zagreb. Patients with tension type headache older than $18 \mathrm{y}$ and 30 healthy volunteers were included. Exclusion criteria were: patients younger than $18 \mathrm{y}$, serious physical or mental illness and use of prophylactic therapy for headaches. The intensity and quality of pain were estimated by visual analog scale (VAS), McGill questionnaire, Brief Pain Inventory (BPI) and presence of depressive symptoms by Beck depression inventory (BDI-II). Descriptive statistical methods and regression analysis were used in statistical analysis.

\section{Results}

The pain intensity in patients with tension type headache was according VAS 51,7+11,86/100mm, McGill questionnaire $15,13+5,06$ points and according BPI 1,9+ 0,86 points. The disability level according BPI was $1,84+$

University Department of Neurology, University Hospital Center "Sestre Milosrdnice", Zagreb, Croatia

(c) 2014 Puretic et al; licensee Springer. This is an Open Access article distributed under the terms of the Creative Commons Attribution License (http://creativecommons.org/licenses/by/2.0), which permits unrestricted use, distribution, and reproduction in any medium, provided the original work is properly cited.
1,33 points. The presence of depressive symptoms was $8,76+4,57$ points, significantly higher than in the control group $(6,26+3,57)$. The regression analysis has not shown any correlation between intensity of pain and presence of depressive symptoms.

\section{Conclusion}

The tension type headache is the chronic pain condition, probably the consequence and not the reason of depressive symptoms.

No conflict of interest.

Published: 18 September 2014

doi:10.1186/1129-2377-15-S1-C7

Cite this article as: Puretic et al:: EHMTI-0196. Tension type headache -

the correlation between pain intensity, depressive symptoms and

impairment of daily functions. The Journal of Headache and Pain 201415 (Suppl 1):C7.

Submit your manuscript to a SpringerOpen ${ }^{\odot}$ journal and benefit from:

- Convenient online submission

- Rigorous peer review

- Immediate publication on acceptance

- Open access: articles freely available online

- High visibility within the field

- Retaining the copyright to your article

Submit your next manuscript at $>$ springeropen.com 